\title{
Tumor suppressor in lung cancer I (TSLCI) alters tumorigenic growth properties and gene expression
}

\author{
Thomas E Sussan ${ }^{1}$, Mathew T Pletcher ${ }^{1}$, Yoshinori Murakami ${ }^{2}$ and \\ Roger H Reeves*1
}

\begin{abstract}
Address: ${ }^{1}$ Department of Physiology, Johns Hopkins University School of Medicine, Baltimore, MD 21205-2185, USA and ${ }^{2}$ Tumor Suppression \& Functional Genomics Project, National Cancer Center Research Institute, Tokyo 104-0045, Japan

Email: Thomas E Sussan - tsussan@jhmi.edu; Mathew T Pletcher - pletcher@scripps.edu; Yoshinori Murakami - ymurakam@gan2.res.ncc.go.jp; Roger H Reeves* - rreeves@jhmi.edu

* Corresponding author
\end{abstract}

Published: 05 August 2005

Molecular Cancer 2005, 4:28 doi:10.1186/1476-4598-4-28
Received: 25 April 2005

Accepted: 05 August 2005

This article is available from: http://www.molecular-cancer.com/content/4/I/28

(C) 2005 Sussan et al; licensee BioMed Central Ltd.

This is an Open Access article distributed under the terms of the Creative Commons Attribution License (http://creativecommons.org/licenses/by/2.0), which permits unrestricted use, distribution, and reproduction in any medium, provided the original work is properly cited.

\begin{abstract}
Background: Introduction of cDNA or genomic clones of the tumor suppressor in lung cancer I $(T S L C l)$ gene into the non-small cell lung cancer line, A549, reverses tumorigenic growth properties of these cells. These results and the observation that $T S L C I$ is down-regulated in a number of tumors suggest that $T S L C l$ functions as a critical switch mediating repression of tumorigenesis.
\end{abstract}

Results: To investigate this mechanism, we compared growth properties of A549 with the TSLCI containing derivative. We found a GI/S phase transition delay in 12.2. Subtractive hybridization, quantitative PCR, and TranSignal Protein/DNA arrays were used to identify genes whose expression changed when TSLCl was up-regulated. Members of common GI/S phase regulatory pathways such as TP53, MYC, RBI and HRAS were not differentially expressed, indicating that TSLCI may function through an alternative pathway(s). A number of genes involved in cell proliferation and tumorigenesis were differentially expressed, notably genes in the Ras-induced senescence pathway. We examined expression of several of these key genes in human tumors and normal lung tissue, and found similar changes in expression, validating the physiological relevance of the A549 and 12.2 cell lines.

Conclusion: Gene expression and cell cycle differences provide insights into potential downstream pathways of $T S L C I$ that mediate the suppression of tumor properties in A549 cells.

\section{Background}

Non-small cell lung cancer (NSCLC) includes squamous and large cell carcinomas and adenocarcinoma. NSCLC accounts for approximately $75 \%$ of all lung cancers diagnosed in the United States [1]. Genetic mutations that activate oncogenes such as KRAS2 and NRAS [2], and loss of function in tumor suppressors such as RB1, TP53, PPP2R1B, CDKN2A, and TSLC1 have been demonstrated in NSCLC tumors [3-7]. 
Table I: Expansion rate of A549 and I 2.2 cell lines. Expansion rates of A549 and I 2.2 cells were determined by counting cells $24 \mathrm{~h}$ and $120 \mathrm{~h}$ after plating $5 \times 10^{4}$ cells. Results of two independent experiments are shown.

\begin{tabular}{ccccc}
\hline Cell line & 24 hours & 120 hours & Fold Increase $(120$ h/24 h) & $\begin{array}{c}\text { Growth Upregulation } \\
\text { (A549/I2.2) }\end{array}$ \\
\hline A549 & $5.73 \times 10^{4}$ & $2.27 \times 10^{6}$ & 39.7 & 3.40 \\
12.2 & $4.53 \times 10^{4}$ & $5.28 \times 10^{5}$ & 11.7 & 3.79 \\
A549 & $2.81 \times 10^{4}$ & $8.12 \times 10^{5}$ & 28.9 & 7.6 \\
12.2 & $3.59 \times 10^{4}$ & $2.74 \times 10^{5}$ & & 3 \\
\hline
\end{tabular}

A549 is derived from an NSCLC adenocarcinoma and displays several properties that are characteristic of transformed cells, including a short cell cycle, loss of contact inhibition, and rapid development of tumors following injection into athymic mice [8]. Introduction of a $1.1 \mathrm{Mb}$ YAC derivative containing the TSLC1 gene into A549 restored TSLC1 expression to normal levels, creating the stable cell line, 12.2 [8]. 12.2 cells do not develop tumors following injection into athymic mice. TSLC1 protein is down-regulated or lost in NSCLC and a number of other neoplastic diseases, including pancreatic [7], hepatocellular [7], breast [9], prostate [10], nasopharyngeal [11], gastric [12], and cervical cancers [13]. Reduction or loss of TSLC1 expression is also observed in cell lines derived from esophageal, ovarian, endometrial, small-cell lung and colorectal tumors [14].

The product of TSLC1 is a transmembrane glycoprotein that forms dimers both within a cell and between adjacent cells to promote cell-cell adhesion [15]. This protein contains structural domains homologous to members of the immunoglobulin superfamily, NCAM adhesion proteins, and the nectin family of $\mathrm{Ca}^{2+}$-independent cell-cell adhesion proteins $[7,16]$. It contains two protein-protein interaction domains that are required for tumor suppressor activity [17]. TSLC1 interacts with the actin cytoskeleton through DAL-1, which implies that it plays a role in cell motility [18]. The TSLC1 gene has been isolated in a number of different experimental paradigms and has received multiple names as a consequence, including IGSF4, BL2, ST17, SynCAM1, SgIGSF, RA175, and NECL2 [16,19-22].

Because TSLC1 by itself can reverse tumorigenic and metastatic properties of the highly aggressive A549 cell line, it is of interest to identify downstream effectors of this potent tumor suppressor. Identification of genes or pathways activated by TSLC1 would help to characterize the molecular switch from tumorigenic to non-tumorigenic growth. We characterized the growth differences that result from restoration of TSLC1 expression to normal levels and used a number of approaches to identify the underlying changes in gene expression. Several genes involved in Ras-induced senescence, endometrial stromal cell decidualization and trophoblast implantation in the uterus were differentially regulated. Additional genes contributing to cell growth, adhesion, and energy production showed altered expression, as well. We did not find evidence that TSLC1 works through any of several previously-characterized cell cycle regulatory pathways. Several expression changes were confirmed in the small amounts of tumor and normal tissue obtained from histological specimens. Thus analysis of this tumor suppressor in the readily accessible A549/12.2 cell system may provide insights into a new gene expression cascade involved in suppression of transformation.

\section{Results \\ TSLCI Alters Growth Properties of A549 Cells}

Introduction of the TSLC1 gene or CDNA into adenocarcinoma-derived A549 cells restores its expression to normal levels and suppresses many tumorigenic properties of this line $[7,8]$. We extended observations about the inhibitory effect of TSLC1 expression on A549 cell growth [8] by showing that 12.2 cells expanded to only $28 \%$ of A549 levels after five days (Table 1 and Fig. 1). This same result was seen with WST-1 reagent, which showed that 48 hours after plating there was a significantly reduced number of viable 12.2 cells relative to A549 (data not shown).

We used flow cytometry to examine how TSLC1 affects apoptosis and cell cycle. Rates of apoptosis in A549 and the TSLC1-expressing 12.2 cell lines were compared after staining with annexin $\mathrm{V}$. No difference was detected in the number of apoptotic cells (Fig. 2A and 2B). Next, we stained cells with propidium iodide and examined cell cycle profiles of A549 and 12.2 (Fig. 2C and Table 2). The 12.2 cell line showed a significant accumulation of cells in G1 phase $(74.4 \%)$ compared to A549 (60.4\%). Fewer 12.2 cells were seen in S and G2/M phase (17.2 and 8.9\%, respectively) when compared to A549 (28.2 and 11.9\%, respectively). Thus, the decreased growth rate of 12.2 is due to reduced cell division, which occurs at least in part to a delay at the G1/S phase checkpoint, resulting in delayed progression into $\mathrm{S}$ phase. 


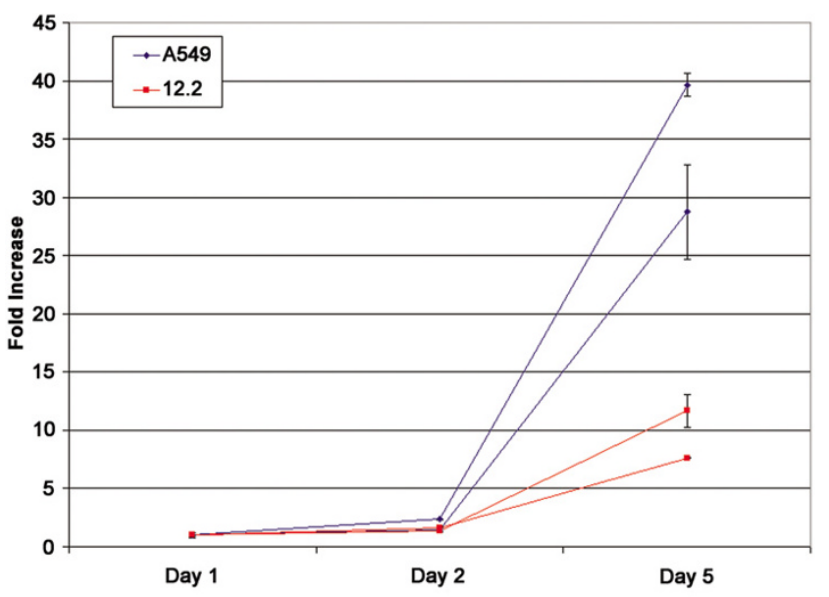

Figure I

Cell doubling assay of A549 and I 2.2 cells. Cell number was counted at Day 2 and Day 5, and normalized to Day I. The results of two independent experiments are shown.

\section{Expression of Signaling Pathway Genes}

Differences in growth rates and cell cycle profiles between A549 and 12.2 led us to examine expression of several known checkpoint and signaling pathway genes using quantitative RT-PCR (qPCR). Alterations in the Ras/p53 pathway result in abnormal G1/S transition in some NSCLC [23]. However, mRNA levels of HRAS, p19, RB1, and TP53 were not substantially different between A549 and 12.2 (Table 3). The minor differences in expression levels were not coordinately regulated in a way that would explain lengthening of the G1/S transition in 12.2 cells. We also examined MYC and cyclin D1 (CCND1), which promote $\mathrm{G} 1$ to $\mathrm{S}$ phase transition. Neither CCND1 nor $M Y C$, its upstream regulator, were differentially expressed. Thus, neither of these established pathways appears to be responsible for the G1 delay.

Alterations in the Wnt/ $\beta$-catenin pathway are commonly observed in colorectal cancers and other solid tumors, including NSCLC. We detected no differences in mRNA levels of three upstream genes in the $\mathrm{Wnt} / \beta$-catenin pathway, disheveled (DVL1), adenomatosis polyposis coli $(A P C)$, and $\beta$-catenin (CTNNB1). However, transcriptional regulators downstream of $\beta$-catenin, TCF4, TCF7L2, and $L E F 1$, were up-regulated in the suppressed 12.2 cell line, by 6.8-, 2.2-, and 3.4-fold, respectively (Table 3).

A549 cells are metastatic in experimental systems [24], and elevated TSLC1 expression is correlated with lower levels of metastasis and invasion in esophageal squamous

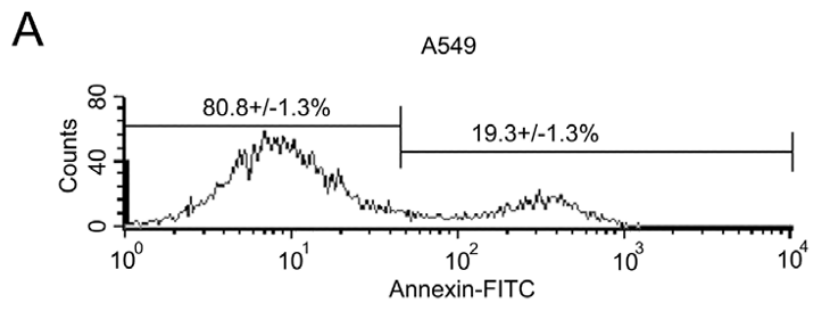

B
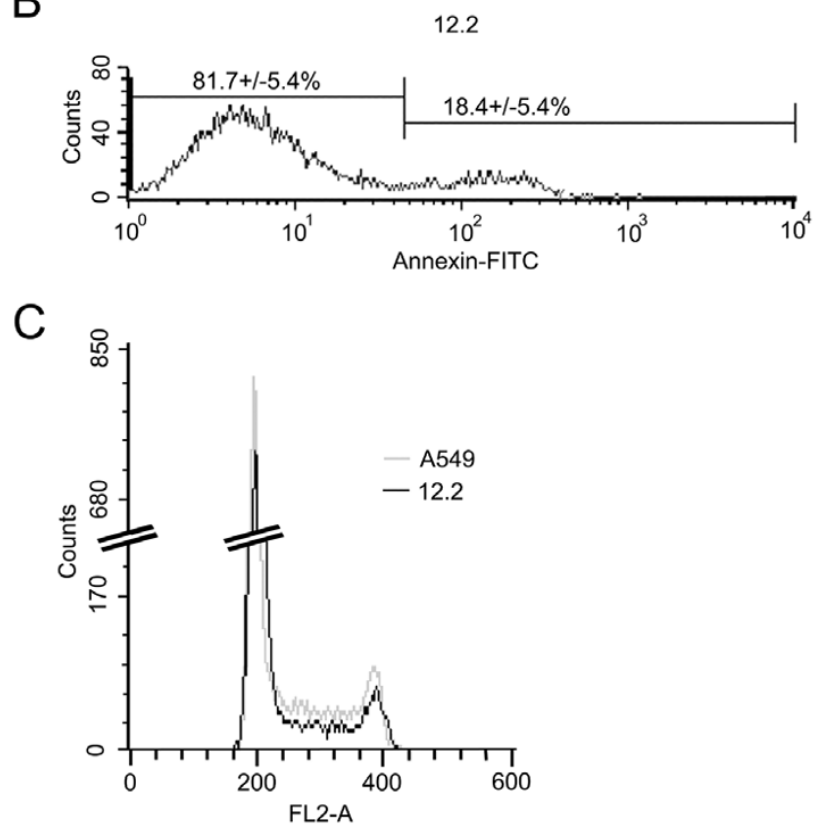

Figure 2

Flow cytometry analysis of apoptosis and cell cycle in A549 and 12.2. Histograms of (A) A549 or (B) I 2.2 cells stained with annexin V-FITC. Percentages are averages of four experiments; histograms are from one representative experiment. (C) Cell cycle histograms of A549 and I2.2.

Cells were fixed, stained with propidium iodide, and analyzed for DNA content by flow cytometry analysis. The left peak represents $2 \mathrm{~N}$ cells in $\mathrm{Gl}$ phase and the right peak represents $4 \mathrm{~N}$ cells in $\mathrm{G} 2 / \mathrm{M}$ phase.

cell carcinoma [25]. Accordingly, we examined levels of several genes involved in angiogenesis and metastasis. Increased expression of the angiogenic factor, VEGF, is correlated with metastasis and poor prognosis in solid tumors [26]. Surprisingly, this gene was up-regulated $4.2+/-0.3$ fold in the suppressed 12.2 cells. Metalloproteinases have roles in various stages of primary tumor progression, invasion and metastasis. In A549 and 12.2, matrix metalloproteinase 1 (MMP1) showed no expression difference, while tissue inhibitor of metalloproteinase 1 (TIMP1) showed a small (2.2+/-0.2-fold) up- 
Table 2: Cell cycle profiles of cell lines determined by flow cytometry. Flow cytometry analysis of cell cycle profiles was determined for A549 and 12.2. Percentages were quantified using CellQuest software. A549 and I2.2 profiles are the means of three experiments. The difference between A549 and I 2.2 is statistically significant $(p<0.005)$.

\begin{tabular}{ccc}
\hline Cell Cycle Stage & \multicolumn{2}{c}{ Percent Total Cells } \\
\cline { 2 - 3 } & A549 & 12.2 \\
\hline GI & $60.4+/-0.3$ & $74.4+/-1.8$ \\
S & $28.2+/-0.5$ & $17.2+/-2.3$ \\
G2/M & $11.9+/-0.7$ & $8.9+/-1.0$ \\
\hline
\end{tabular}

regulation in 12.2. These results show that some genes associated with metastasis are altered by TSLC1, but not necessarily as predicted by previously described pathways in tumorigenic cells.

\section{Proteomic Analysis of Transcription Factors}

We characterized changes in transcription factor (TF) expression more broadly using the TranSignal Protein/ DNA Array I (Panomics Inc., Redwood City, CA). Of the 54 TFs analyzed, 4 were down-regulated 2-fold or more in the 12.2 line and 8 were up-regulated in 12.2 (Table 3 ). In general, those up-regulated in 12.2 have been previously associated with repression of tumorigenesis. E2F1, which regulates the $\mathrm{G} 1 / \mathrm{S}$ phase transition and has tumor suppressor properties, is increased in 12.2 , consistent with our results from cell cycle analysis. The signal transducer and activator of transcription (Stat) proteins, which promote cellular proliferation, were down-regulated in 12.2. Interestingly, several TFs commonly disregulated in cancer, including AP-1, c-Myb, Ets, Sp1, Myc-associated factor $\mathrm{X}, \mathrm{NF \kappa B}$ and p53, were not altered between A549 and 12.2. (For complete list of TFs analyzed, see http:// www.panomics.com/PDarray1 references.htm. These results are consistent with $\mathrm{qPCR}$ expression analysis, which did not show differences in cDNA levels for TP53, MYC, and ETS2 (Table 3).

\section{Differential gene expression analysis}

Subtractive hybridization was performed between A549 cells and the suppressed 12.2 cells to identify genes differentially expressed when TSLC1 is restored to normal levels. The procedure was performed in both directions to produce two populations of cDNA enriched for messages up-regulated in A549 or in 12.2, respectively. Each of the differentially expressed cDNA populations was hybridized to Genome Systems cDNA arrays, identifying 41 genes greatly over-expressed in the tumorigenic A549 line and 18 genes over-expressed in the suppressed 12.2 cell line (Table 3 ). The differentially expressed genes represented a variety of functional classes, including those with roles in cell proliferation, cell survival, protein phosphorylation, immune response, cell adhesion, or detoxification. Several genes whose products are localized to the mitochondria were also differentially expressed.

Relative transcript levels for 31 of the differentiallyexpressed genes were quantified using qPCR (Table 3). Expression was normalized to glyceraldehyde 3-phosphate dehydrogenase (GAPDH) and alpha-tubulin (TUBA1). qPCR showed that TSLC1 expression was 2.8+/ -0.8 times higher in 12.2 than in A549, as expected. Twenty-one of the 31 genes analyzed by qPCR showed expression differences of 2-fold or more in the direction predicted by subtractive hybridization. One gene, complement component C5 (CCC5), showed a 13.8+/-4.7-fold down-regulation in 12.2 cells, contrary to results expected after subtractive hybridization. The nine remaining genes changed less than 2-fold.

Several genes involved in cellular proliferation were among those expressed at high levels in A549 but low levels in 12.2 (Table 3). Cadherin 11 (CDH11), which plays a role in cell-cell interactions was also down-regulated in 12.2. Furthermore, several mitochondrial genes were down-regulated in 12.2 (Table 3). The genes that were most highly up-regulated with the restoration of TSLC1 expression in 12.2 cells were the candidate tumor suppressor Ras-induced senescence 1 (RIS1), metallothionein 1G (MT1G) and metallothionein 1E (MT1E).

\section{Gene expression in tumor vs. normal tissue}

We compared gene expression in normal vs. tumor tissue to determine whether differences in 12.2 and A549 cells reflect changes that occur in vivo (Table 4). Tissue was recovered from pathological specimens and transcript levels were measured by qPCR, normalized to GAPDH as described [14]. TSLC1 and RIS1 levels were lower than normal in 5/5 tumor specimens, while S100 calciumbinding protein $\mathrm{P}$ (S100P) and insulin-like growth factor binding protein 1 (IGFBP1) levels were elevated in 5/5 and $4 / 5$ tumors, respectively. Thus, key differences observed between the transformed (A549) and suppressed (12.2) cell lines reflect physiological differences seen in tumor vs. normal tissue.

\section{Discussion}

Restoration of TSLC1 expression to normal levels in A549 cells reverses several transformed properties of this line, slowing the growth rate, restoring contact inhibition, eliminating its ability to form tumors in nude mice and blocking metastasis. In this study, we have shown that restoration of TSLC1 expression in 12.2 cells reduced cell growth by 3.6-fold. This change in growth rate dynamics was not due to an increase in the number of apoptotic cells. Rather, flow cytometry revealed that 12.2 cells expe- 
Table 3: Comparison of gene expression in A549 and I 2.2 cell lines. Genes expressed differentially between A549 and I 2.2 cells were identified by qPCR, subtractive hybridization (SH), and/or TransSignal DNA-protein array (TS) as indicated. Relative quantification differences were determined for those genes analyzed by either qPCR or TS. ND, not determined.

\begin{tabular}{|c|c|c|c|c|}
\hline Gene & Up-Regulated & Assay & $\begin{array}{l}\text { Fold Expression } \\
\text { Difference }\end{array}$ & Functional Class \\
\hline Fibrinogen beta chain (FGB) & A549 & $\mathrm{SH} / \mathrm{qPCR}$ & $2737.5+/-1058.5$ & Adhesion \\
\hline Fibrinogen gamma chain (FGG) & A549 & $\mathrm{SH}$ & ND & Adhesion \\
\hline Adenomatosis polyposis coli (APC)* & A549 & qPCR & $1.7+/-0.2$ & Cellular Growth \\
\hline Cyclin DI (CCNDI) ${ }^{\dagger}$ & A549 & qPCR & $1.6+/-0.0$ & Cellular Growth \\
\hline$\beta$-catenin I $(C T N N B I)^{*}$ & 12.2 & $\mathrm{qPCR}$ & $1.1+/-0.0$ & Cellular Growth \\
\hline Dishevelled I $(D V L I)^{*}$ & A549 & qPCR & $1.1+/-0.3$ & Cellular Growth \\
\hline $\begin{array}{l}\text { v-Ha-ras Harvey rat sarcoma viral oncogene homolog } \\
(H R A S)^{\dagger}\end{array}$ & A549 & qPCR & $1.4+/-0.3$ & Cellular Growth \\
\hline Lymphoid enhancer-binding factor I (LEFI)* & 12.2 & qPCR & $3.4+/-0.4$ & Cellular Growth \\
\hline $\begin{array}{l}\text { v-myc myelocytomatosis viral oncogene homolog } \\
(\text { MYC })^{\dagger}\end{array}$ & A549 & qPCR & $1.3+/-0.2$ & Cellular Growth \\
\hline Interleukin 23-alpha $(p / 9)^{\dagger}$ & A549 & qPCR & $1.0+/-0.0$ & Cellular Growth \\
\hline Tumor protein p53 (TP53) & A549 & qPCR & $1.7+/-0.3$ & Cellular Growth \\
\hline Retinoblastoma I $(R B I)^{\dagger}$ & 12.2 & qPCR & $1.3+/-0.4$ & Cellular Growth \\
\hline SI00 calcium-binding protein $\mathrm{P}$ (SIOOP) & A549 & $\mathrm{SH} / \mathrm{qPCR}$ & $1680.0+/-955.4$ & Cellular Growth \\
\hline Transcription factor 4 (TCF4)* & 12.2 & qPCR & $6.8+1-2.0$ & Cellular Growth \\
\hline Transcription factor 7-like 2 (TCF7L2)* & 12.2 & qPCR & $2.2+/-0.7$ & Cellular Growth \\
\hline Transmembrane 4 superfamily member (TM4SF4) & A549 & $\mathrm{SH} / \mathrm{qPCR}$ & $475.2+/-328.0$ & Cellular Growth \\
\hline Centromere protein $\mathrm{E}(\mathrm{CENPE})$ & A549 & $\mathrm{SH}$ & & Cellular Growth \\
\hline Heat shock protein 70B (HSPA6) & A549 & $\mathrm{SH} / \mathrm{qPCR}$ & $2.4+/-0.8$ & Chaperone \\
\hline Insulin-like growth factor binding protein I (IGFBPI) & A549 & $\mathrm{SH} / \mathrm{qPCR}$ & $15.9+/-7.4$ & Decidualization [4I] \\
\hline Retinoid X receptor RXR (DR-I) & A549 & TS & 2.7 & Decidualization [42] \\
\hline Aldehyde dehydrogenase I (ALDHI) & A549 & $\mathrm{SH} / \mathrm{qPCR}$ & $4.2+/-0.1$ & Decidualization-Implantation [43] \\
\hline Annexin A2 (Lipocortin II) (ANXA2) & 12.2 & $\mathrm{SH} / \mathrm{qPCR}$ & $3.1+/-1.0$ & Decidualization-Implantation [43] \\
\hline Metallothionein-IF (MTIF) & 12.2 & $\mathrm{SH}$ & ND & Decidualization-Implantation [43] \\
\hline Metallothionein-IG (MTIG) & 12.2 & $\mathrm{SH} / \mathrm{qPCR}$ & $37.1+/-10.4$ & Decidualization-Implantation [43] \\
\hline Cadherin II (OB-cadherin, osteoblast) (CDHII) & A549 & $\mathrm{SH} / \mathrm{qPCR}$ & $5.6+/-2.7$ & $\begin{array}{l}\text { Decidualization-Luteal/Adhesion } \\
{[34,44]}\end{array}$ \\
\hline Fibroblast growth factor 9 (FGF9) & A549 & $\mathrm{SH}$ & ND & Decidualization-Proliferation [45] \\
\hline Promyelocytic leukemia gene (PML) & A549 & $\mathrm{SH}$ & ND & Decidualization-Proliferation \\
\hline Similar to aldehyde dehydrogenase 6 (ALDHIA3) & A549 & $\mathrm{SH}$ & ND & Dehydrogenase \\
\hline $\begin{array}{l}\text { 3-alpha hydroxysteroid dehydrogenase type II } \\
(A K R I C 3)\end{array}$ & A549 & $\mathrm{SH}$ & ND & Dehydrogenase \\
\hline Dihydrodiol dehydrogenase 2 (AKR/C2) & A549 & $\mathrm{SH} / \mathrm{qPCR}$ & $22.9+/-2.4$ & Dehydrogenase \\
\hline Kinesin 2, light chain (KNS2) & 12.2 & $\mathrm{SH} / \mathrm{qPCR}$ & $3.9+/-0.0$ & Intracellular Trafficking \\
\hline Matrix metalloproteinase I (MMPI) & 12.2 & qPCR & $1.2+/-0.4$ & Invasion \\
\hline Vascular endothelial growth factor (VEGF) & 12.2 & qPCR & $4.2+/-0.3$ & Invasion \\
\hline Ferritin, heavy chain $(F T H I)$ & 12.2 & $\mathrm{SH} / \mathrm{qPCR}$ & $2.7+/-1.7$ & Iron Binding \\
\hline Metallothionein-IE (MTIE) & 12.2 & $\mathrm{SH} / \mathrm{qPCR}$ & $14.8+/-8.5$ & Metal Homeostasis \\
\hline Metallothionein-IH $(M T I H)$ & 12.2 & $\mathrm{SH}$ & ND & Metal Homeostasis \\
\hline Metallothionein-IL (MTIL) & 12.2 & $\mathrm{SH} / \mathrm{qPCR}$ & $5.8+/-0.9$ & Metal Homeostasis \\
\hline Metallothionein-IR (MTIR) & 12.2 & $\mathrm{SH}$ & ND & Metal Homeostasis \\
\hline Manganese-containing superoxide dismutase (SOD2) & A549 & $\mathrm{SH} / \mathrm{qPCR}$ & $2.0+/-0.6$ & Mitochondrial \\
\hline Microsomal glutathione transferase (MGSTI) & A549 & $\mathrm{SH} / \mathrm{qPCR}$ & $2.3+/-0.1$ & Mitochondrial \\
\hline $\begin{array}{l}\text { NAD(P)H menadione oxidoreductase I, dioxin-inducible } \\
\text { (NQOI) }\end{array}$ & A549 & $\mathrm{SH} / \mathrm{qPCR}$ & $3.1+/-0.1$ & Mitochondrial \\
\hline Solute carrier family 25 member 5 (SLC25A5) & A549 & $\mathrm{SH} / \mathrm{qPCR}$ & $3.4+/-0.3$ & Mitochondrial \\
\hline Myelin proteolipid protein (PLP) & A549 & $\mathrm{SH}$ & ND & Myelin Constituent \\
\hline Ribosomal protein S6 (RPS6) & 12.2 & $\mathrm{SH} / \mathrm{qPCR}$ & $2.5+/-1.2$ & Protein Kinase \\
\hline $\begin{array}{l}\text { v-ets erythroblastosis virus E26 oncogene homolog } 2 \\
\text { (ETS2) }\end{array}$ & A549 & qPCR & $1.2+/-0.0$ & Ras-Induced Senescence [29] \\
\hline Metallothionein-II (MTII) & 12.2 & $\mathrm{SH}$ & ND & Ras-Induced Senescence [29] \\
\hline Ras induced senescence I (RISI) & 12.2 & $\mathrm{SH} / \mathrm{qPCR}$ & $80.2+/-62.3$ & Ras-Induced Senescence [29] \\
\hline Tissue inhibitor of metalloproteinase I (TIMPI) & 12.2 & qPCR & $2.2+/-0.1$ & Ras-Induced Senescence [29] \\
\hline CAAT box general (CBF) & 12.2 & TS & 2.5 & Transcription Factor \\
\hline CCAAT displacement protein (CDP) & 12.2 & TS & 2 & Transcription Factor \\
\hline E2F transcription factor I (E2F-I) & 12.2 & TS & 2.4 & Transcription Factor \\
\hline
\end{tabular}


Table 3: Comparison of gene expression in A549 and I 2.2 cell lines. Genes expressed differentially between A549 and I 2.2 cells were identified by qPCR, subtractive hybridization (SH), and/or TransSignal DNA-protein array (TS) as indicated. Relative quantification differences were determined for those genes analyzed by either qPCR or TS. ND, not determined. (Continued)

\begin{tabular}{|c|c|c|c|c|}
\hline Early growth response (EGR) & 12.2 & TS & 3.4 & Transcription Factor \\
\hline Estrogen receptor (ERE) & 12.2 & TS & 2.5 & Transcription Factor \\
\hline GATA binding protein (GATA) & 12.2 & TS & 2.1 & Transcription Factor \\
\hline Glucocorticoid receptor (GRE) & 12.2 & TS & 3 & Transcription Factor \\
\hline $\begin{array}{l}\text { Nuclear factor of activated T-cells, cytoplasmic (NF- } \\
\text { ATc) }\end{array}$ & 12.2 & TS & 3.1 & Transcription Factor \\
\hline $\begin{array}{l}\text { Signal transducer and activator or transcription } 3 \\
\text { (STAT3) }\end{array}$ & A549 & TS & 2 & Transcription Factor \\
\hline $\begin{array}{l}\text { Signal transducer and activator or transcription } 4 \\
\text { (STAT4) }\end{array}$ & A549 & TS & 2.3 & Transcription Factor \\
\hline Upstream transcription factor (USF-I) & A549 & TS & 2.5 & Transcription Factor \\
\hline Transcription co-activator Spl I0 & A549 & $\mathrm{SH}$ & ND & Transcription Factor \\
\hline $\begin{array}{l}\text { Similar to eukaryotic translation initiation factor 2B, } \\
\text { subunit I (EIF2BI) }\end{array}$ & A549 & $\mathrm{SH}$ & ND & Translation \\
\hline Insulin-like 4 (INSL4) & A549 & $\mathrm{SH} / \mathrm{qPCR}$ & $27.0+/-15.8$ & Trophoblast [46] \\
\hline Keratin 8 (KRT8) & A549 & $\mathrm{SH}$ & ND & Trophoblast [47] \\
\hline cDNA clone DKFZp76ICI(ALI57447) & A549 & $\mathrm{SH}$ & ND & Unknown \\
\hline cDNA clone FLJ20643 (AK000650) & A549 & $\mathrm{SH}$ & ND & Unknown \\
\hline FLJI 4639 (NM_0328I5) & A549 & $\mathrm{SH}$ & ND & Unknown \\
\hline Hit clone 45IB2I (AL033522) & A549 & $\mathrm{SH}$ & ND & Unknown \\
\hline HSAIp34 genomic sequence (AL009I8I) & A549 & $\mathrm{SH}$ & ND & Unknown \\
\hline Rhomboid family I (Z697I9) (RHBDFI) & A549 & $\mathrm{SH}$ & ND & Unknown \\
\hline RPII-2H8 (AC089984) & A549 & $\mathrm{SH}$ & ND & Unknown \\
\hline RPII-389E6 (AL359836) & A549 & $\mathrm{SH}$ & ND & Unknown \\
\hline RPII-478JI8 (ACOII700) & A549 & $\mathrm{SH}$ & ND & Unknown \\
\hline RPII-7F24 (AC0I884I) & A549 & $\mathrm{SH}$ & ND & Unknown \\
\hline RPI-20C7 (ALI36304) & A549 & $\mathrm{SH}$ & ND & Unknown \\
\hline SR+89 (Z69706) & A549 & $\mathrm{SH}$ & ND & Unknown \\
\hline HSAI4 genomic sequence (ALI35745) & 12.2 & $\mathrm{SH}$ & ND & Unknown \\
\hline
\end{tabular}

*Wnt/ß-catenin pathway

†GI/S transition

Table 4: Gene expression profiles in NSCLC tumor vs. normal lung parallel those in A549 and I 2.2 Relative fold expression differences, determined by qPCR, were determined in tumors and compared to normal lung tissue from same patient. Positive values represent higher expression in tumor; negative values represent higher expression in normal tissue.

\begin{tabular}{lcccc}
\hline & \multicolumn{4}{c}{ Relative Gene Expression in Tumors } \\
\cline { 2 - 5 } & TSLCI & RISI & SI00P & IGFBPI \\
\cline { 2 - 5 } Patient I & -25.7 & -2.3 & 33.3 & 600 \\
Patient 2 & -23.8 & -6.4 & 2.1 & 2.3 \\
Patient 3 & -16.9 & -7.1 & 3.1 & -8.4 \\
Patient 4 & -344.3 & -43.9 & 16.1 & 1.9 \\
Patient 5 & -32.4 & -44.9 & UP in A549 & UP in A549 \\
Cell Lines & Down in A549 & Down in A549 & &
\end{tabular}

rience a delay relative to A549 cells in progression from G1 to $S$ phase of the cell cycle. These differences in growth related properties between A549 and 12.2 were similar to those observed previously when tumor cells were trans- fected with a vector containing TSLC1 cDNA or genomic clone $[7,8,25]$. These phenotypic differences led us to examine expression of genes associated with adhesion, invasion, basal metabolism, cell growth, senescence and 
apoptosis in A549 and 12.2 to identify classes of genes altered by restoration of TSLC1 expression in 12.2.

The most highly up-regulated gene in 12.2 cells was the putative tumor suppressor, Ras-induced senescence 1 (RIS1). RIS1 is located at $3 \mathrm{p} 21.3$, which is a region that is deleted in many human tumors [27]. Also, RIS1 is located within a $1 \mathrm{Mb}$ human chromosomal region that is commonly deleted during tumor formation in human/mouse microcell hybrids that are passaged through severe combined immunodefficient (SCID) mice [28]. This region, called chromosome 3 common eliminated region 1 (CER1), has been posited to contain one or more currently unidentified tumor suppressors. Our results provide support for RIS1 as a candidate.

Coordinate up-regulation of RIS1, metallothionein II, and TIMP1 was observed in Ras-induced senescent cells [29]. Consistent with this study, we found increased levels of RIS1, several metallothioneins, and TIMP1 in 12.2 cells. Activation of these genes suggests that TSCL1-mediated inhibition of tumorigenesis may be related to the Rasinduced senescence pathway. However, previous studies showed that RIS1 expression is dependent on ETS2, an inducer of Ras-induced senescence, in human fibroblast IMR90 cells [29]. ETS2 was not differentially expressed between A549 and 12.2 cells in this study (Table 3) suggesting that RIS1 is activated in 12.2 cells through a different pathway.

Several genes were identified that have known roles in cancer. S100P, which was down-regulated in the nontumorigenic 12.2 cell line, is involved in cell growth and has been previously implicated in prostate [30] and breast cancer progression [31]. It is over-expressed in lung adenocarcinomas [32], which frequently exhibit reduced levels of TSLC1 expression[7]. However, down-regulation of S100P in A549 using antisense RNA was not sufficient to alter growth related phenotypes by itself (data not shown). Insulin-like growth factor 4 (INSL4), also downregulated in 12.2, has been reported to be over-expressed in highly invasive breast cancer cells [33]. Reduced expression of S100P and INSL4 in 12.2 may contribute to the slower growth rate and loss of tumorigenic properties in the 12.2 cell line when TSLC1 expression is restored to normal levels.

Several differentially expressed genes identified in this study have been previously shown, in non-overlapping experiments, to be differentially expressed during various stages of endometrial stromal cell decidualization and trophoblast implantation (Table 3). The relationship between these processes and neoplastic transformation in NSCLC is not clear. However, it is interesting that these seemingly unrelated events show similar patterns of gene expression changes. Decidualization and implantation are characterized by high levels of proliferation and tissue invasion; properties shared with transformed cells. Together, these observations suggest that TSLC1 may repress transformed growth via some of the same pathways that regulate proliferation in endometrial cells during various stages of decidualization.

Subtractive hybridization and qPCR showed that restoration of TSLC1 lowered expression of CDH11, an adhesion protein that may enhance cellular invasion [34]. CDH11 is expressed in highly invasive but not in noninvasive breast cancer cell lines $[34,35]$. It has been shown to associate with $\beta$-catenin (CNNTB1)[36]. While we did not see a significant difference in expression of upstream genes in the Wnt-1/ $\beta$-catenin pathway (DVL1, CDKN2A, CNNTB1) between A549 and 12.2, we did see expression differences in CTNNB1-dependent transcription factors LEF1, TCF4, and TCF7L2, which were up-regulated in 12.2. This may be a consequence of down-regulation of CDH11 leading to lower levels of CNNTB1 sequestered at the plasma membrane. This unbound CNNTB1 could then translocate to the nucleus to activate downstream genes. Retera et. al. [37] demonstrated that CNNTB1 expression is reduced in NSCLC primary tumors and metastases. Our results suggest that downstream effectors of CNNTB1, such as LEF1, TCF4, and TCF7L2, may be involved in suppressing tumorigenic properties in 12.2.

Although the growth difference in A549 and 12.2 is characterized by a significant delay at G1/S in the latter, we did not find significant changes in gene expression for common G1/S phase regulators HRAS, p19, RB1, TP53, MYC, and CCND1. Also, the increased expression of VEGF in 12.2 cells contrasts with observations from many tissues which show that this gene is up-regulated in tumor cells. This suggests that TSLC1 does not suppress tumorigenesis through any of these common pathways. However, several of these genes are regulated at the protein level or through localization to the nucleus. In order to address this concern, we examined c-Myc and cyclin D1 protein levels by western blot, and found no difference in expression between A549 and 12.2 (data not shown). Furthermore, the Panomics TranSignal Protein/DNA Array found no difference in expression of Myc-associated factor $\mathrm{X}$, NFKB, c-Myb, and AP-1.

Cell lines are artifactual by definition, and they do not perfectly replicate in vivo conditions. However, comparison of key gene expression patterns in matched tumornormal tissue pairs showed that our results with A549 and 12.2 are representative of in vivo expression levels. These results validate the physiological relevance of our in vitro expression analysis in a model system that is far more 
amenable to experiment than is the minute amount of material recovered from histological specimens.

It is notable that acute expression of high levels of TSLC1 in A549 cells has a somewhat different effect on cell cycle profiles than does the long-term restoration of this gene in 12.2 cells. Infection for 3 or 5 days with adenovirus vectors expressing a TSLC1 CDNA (Ad-TSLC1) induced apoptosis and increased annexin $\mathrm{V}$ staining in infected cultures [38]. This contrasts with stable restoration of TSLC1 expression in the 12.2 line, which does not demonstrate elevation in annexin $\mathrm{V}$ staining. Since the 12.2 cell line was selected after transfection of TSLC1, it adds valuable insights into the normal function of TSLC1 in non-transformed cells. TSLC1 has the ability to suppress the transformed growth properties of A549, and it alters the gene expression profile of A549 to resemble that of normal relative to transformed lung tissue. A part of its normal function as a potent tumor suppressor may be to regulate cell growth by initiating apoptosis in those rare cells that initiate neoplastic transformation.

\section{Conclusion}

Restoration of TSLC1 levels in the tumorigenic A549 cell line resulted in a loss of transformed growth properties, including a reduced cell doubling rate and a delayed progression from G1 to S phase during the cell cycle. This corresponded with a change in the gene expression profile, including changes in genes with roles in Ras-induced senescence and endometrial decidualization. Other genes with roles in cell proliferation were also altered when TSLC1 levels were restored, including IGFBP1, S100P, and INSL4. TSLC1 does not appear to act through any of several well-characterized cell growth regulatory pathways.

Elucidating the mechanisms by which TSLC1 represses tumorigenesis would have an important impact on the understanding of cancer biology in the lung, as well as in the numerous other tissues where TSLC1 has been associated with cancer progression. This study reveals several cellular phenotypes associated with TSLC1 expression and provides insights into the genes and molecular pathways induced by TSLC1.

\section{Methods}

\section{Cell Culture and Tumor Samples}

The A549 cell line (American Type Culture Collection [ATCC], Manassas, VA) was cultured in Dulbecco's modified Eagle's medium (Invitrogen Corp., Carlsbad, CA) supplemented with $10 \%$ fetal bovine serum (Hyclone Laboratories, Inc., Logan UT), $1 \mathrm{X}$ non-essential amino acids and $1 \%$ penicillin-streptomycin (Invitrogen Corp., Carlsbad, CA) in 5\% $\mathrm{CO}_{2}$. The suppressed 12.2 cell line was created by transfecting YAC derivative y939-95 into A549 cells [8]. 12.2 cells were cultured under the same conditions as A549, with the addition of $500 \mu \mathrm{g} / \mathrm{ml} \mathrm{G418}$ (Mediatech, Inc., Herndon, VA), except for cell growth assays, in which G418 was omitted.

For the growth assays, duplicate aliquots of $5 \times 10^{4}$ cells were plated in six-well dishes. After 24, 48, and $120 \mathrm{~h}$, cells were trypsinized and three aliquots from each well were counted using a hemacytometer. The average of six counts (three each, for two wells) is reported here.

For the WST-1 cellular proliferation assay (Roche Applied Science, Indianapolis, IN), $1 \times 10^{4}$ cells were cultured for $48 \mathrm{~h}$. Samples were incubated with WST-1 reagent for $1 \mathrm{~h}$, and absorbance was measured at $450 \mathrm{~nm}$ and $620 \mathrm{~nm}$.

Five primary NSCLC tumors and corresponding non-cancerous lung tissues from the same patients were surgically resected and histologically diagnosed at National Cancer Center, Japan. All samples were immediately frozen after surgical resection and stored at $-135^{\circ} \mathrm{C}$. The analyses of human samples were carried out in accordance with the institutional guidelines.

\section{Proteomic Analysis}

Proteomic analysis was performed using the TranSignal Protein/DNA Array I (Panomics Inc., Redwood City, CA). Nuclear protein extracts from A549 or 12.2 were incubated with an excess of biotinylated cis-binding elements (CBE) of 54 common transcription factors (TFs). Unbound CBE were removed and the protein/DNA complexes were separated, leaving labeled CBE which represent the relative protein levels of the $54 \mathrm{TFs}$. These were hybridized to a DNA array and visualized using streptavidin-HRP. Hybridized probe was quantified using the AlphaImager v5.5 software (Alpha Innotech Corp. San Leandro, CA).

\section{Subtractive Hybridization}

Total RNA was isolated from A549 and 12.2 using Trizol reagent (Invitrogen Corp.), and poly(A) mRNA was purified using the PolyATract mRNA Isolation System II (Promega, Madison, WI). Subtractive hybridization was performed between A549 and 12.2 in both directions using the PCR-Select cDNA Subtraction Kit (Clontech, Palo Alto, CA).

The enriched pools of cDNA were hybridized to human Gene Discovery Array cDNA nylon filters (Genome Systems, Inc., St. Louis, MO). Samples $(15 \mu \mathrm{l})$ of the final PCR reaction from each subtractive hybridization reaction were radioactively labeled by random prime-labeling with [32P]dCTP [39,40] and purified using ProbeQuant G-50 Sephadex columns (Amersham Pharmacia Biotech, Inc., Piscataway, NJ). The filters were prehybridized for $2 \mathrm{~h}$ at $42{ }^{\circ} \mathrm{C}$ in buffer consisting of $0.75 \mathrm{M} \mathrm{NaCl}, 0.1 \mathrm{M}$ 
$\mathrm{Na}_{2} \mathrm{HPO}_{4}, 0.1 \% \mathrm{Na}_{4} \mathrm{P}_{2} \mathrm{O}_{7}-10 \mathrm{H}_{2} \mathrm{O}, 0.15 \mathrm{M}$ Tris (pH 7.5), 5X Denhardt's solution, 2\% SDS, and $100 \mu \mathrm{g} / \mathrm{ml}$ sheared salmon testis DNA (Sigma-Aldrich, St. Louis, MO). Probes were hybridized overnight at $42^{\circ} \mathrm{C}$ in the same buffer.

The membranes were washed in 2X SSC for $5 \mathrm{~min}$ at room temperature, twice in $2 \mathrm{X}$ SSC with $1 \%$ SDS for $30 \mathrm{~min}$ at $68^{\circ} \mathrm{C}$, and twice in $0.6 \mathrm{X}$ SSC with $1 \%$ SDS for $30 \mathrm{~min}$ at $68^{\circ} \mathrm{C}$. The filters were then rinsed in room-temperature 2X SSC and placed on film for 3 days for the A549 overexpressed population and 2 weeks for the 12.2 overexpressed isolates. Identities of associated EST sequences for positive clones were obtained from the Genome Systems website http://reagents.incyte.com/GDA/ geneID.html. EST sequences were analyzed by BLAST, using the non-redundant database to obtain gene annotation for positive clones.

\section{Quantitative PCR}

RNA was isolated from A549, 12.2, or the antisense clones with Trizol reagent (Invitrogen Corp.) and used to generate cDNA using Superscript II reverse transcriptase (Invitrogen Corp.). Quantitative PCR (qPCR) was carried out using the LightCycler rapid thermal cycler system and the SYBR Green FastStart PCR kit (Roche Diagnostics Ltd., Lewes UK). Primers were used at $0.5 \mu \mathrm{M}$ and $\mathrm{MgCl}_{2}$ at 4 $\mathrm{mM}$. Samples were heat-denatured for $10 \mathrm{~min}$., then cycled 55 times at $95^{\circ} \mathrm{C}$ for $10 \mathrm{sec}$., $58^{\circ} \mathrm{C}$ for $5 \mathrm{sec}$., and $72^{\circ} \mathrm{C}$ for $20 \mathrm{sec}$. At the completion of the cycling, a melting curve analysis was performed to detect the presence of multiple products. A standard curve was generated based on serial dilutions of PAC 66B10 and primers for marker 66B10.SP6 (CCTGGTAGTGGATTTCCCAA and ATGCCATTCAGTTTGTTCCC). Samples were normalized to glyceraldehyde 3-phosphate (ACCACAGTCCATGCCATCAC and TCCACCACCCTGTTGCTGTA). Primers for each gene were designed using the Primer3 program http://www-genome.wi.mit.edu/cgi-bin/primer/ primer3.cgi.

\section{Flow Cytometry}

For the apoptosis assay, A549 and 12.2 cells were grown without antibiotic selection. Cells were trypsinized and stained with annexin $\mathrm{V}$ and propidium iodide as recommended (BD Biosciences Pharmingen, San Diego, CA). Cells were analyzed on a Becton Dickinson FACScan.

For cell cycle studies, $2 \times 10^{6}$ cells were collected and resuspended in $1 \mathrm{ml}$ cold PBS, and $4 \mathrm{ml}$ of $-20^{\circ} \mathrm{C} 100 \%$ ethanol was slowly added. Cells were stored at $-20^{\circ} \mathrm{C}$ overnight, recovered by centrifugation and resuspended in $1 \mathrm{ml}$ PBS. RNase A $(20 \mu \mathrm{g} / \mathrm{ml})$ (Sigma-Aldrich Chemical Co., St. Louis, MO) was added, and the samples were incubated at $37^{\circ} \mathrm{C}$ for $30 \mathrm{~min}$. Samples were incubated in $100 \mu \mathrm{g} / \mathrm{ml}$ propidium iodide (Sigma-Aldrich Chemical
Co.) at room temperature for at least $1 \mathrm{~h}$ prior to analysis on a Becton Dickinson FACScan.

\section{Authors' contributions}

TES carried out qPCR, protein analysis, flow cytometry, and drafted the manuscript. MTP performed the subtractive hybridization. YM acquired and analyzed tumor and normal lung tissue. RHR was responsible for the study design and coordinated data analysis.

\section{Acknowledgements}

We would like to thank David Graham (Johns Hopkins School of Medicine, Baltimore, MD) for his comments on the manuscript. Insightful comments on the design and interpretation of these experiments were provided by Chi Van Dang (Johns Hopkins School of Medicine, Baltimore, MD). This work was supported by PHS awards HD24605 and HD38384 (RHR).

\section{References}

I. Ihde DC, Minna JD: Non-small cell lung cancer. Part I: Biology, diagnosis, and staging. Curr Probl Cancer 199I, 15:6I-104.

2. Suzuki Y, Orita M, Shiraishi M, Hayashi K, Sekiya T: Detection of ras gene mutations in human lung cancers by single-strand conformation polymorphism analysis of polymerase chain reaction products. Oncogene 1990, 5:1037-1043.

3. Birrer MJ, Minna JD: Genetic changes in the pathogenesis of lung cancer. Annu Rev Med 1989, 40:305-317.

4. Kishimoto Y, Murakami Y, Shiraishi M, Hayashi K, Sekiya T: Aberrations of the p53 tumor suppressor gene in human non-small cell carcinomas of the lung. Cancer Res 1992, 52:4799-4804.

5. Sachse R, Murakami Y, Shiraishi M, Hayashi K, Sekiya T: DNA aberrations at the retinoblastoma gene locus in human squamous cell carcinomas of the lung. Oncogene 1994, 9:39-47.

6. Wang SS, Esplin ED, Li JL, Huang L, Gazdar A, Minna J, Evans GA: Alterations of the PPP2RIB gene in human lung and colon cancer. Science 1998, 282:284-287.

7. Kuramochi M, Fukuhara $H$, Nobukuni $T$, Kanbe $T$, Maruyama $T$, Ghosh HP, Pletcher M, Isomura M, Onizuka M, Kitamura T, Sekiya T, Reeves RH, Murakami Y: TSLCI is a tumor-suppressor gene in human non-small-cell lung cancer. Nat Genet 200I, 27:427-430.

8. Murakami Y, Nobukuni T, Tamura K, Maruyama T, Sekiya T, Arai Y, Gomyou H, Tanigami A, Ohki M, Cabin D, Frischmeyer P, Hunt P, Reeves RH: Localization of tumor suppressor activity important in nonsmall cell lung carcinoma on chromosome IIq. Proc Natl Acad Sci U S A 1998, 95:8153-8I58.

9. Allinen M, Peri L, Kujala S, Lahti-Domenici J, Outila K, Karppinen SM, Launonen V, Winqvist R: Analysis of I I q2 I-24 loss of heterozygosity candidate target genes in breast cancer: indications of TSLCI promoter hypermethylation. Genes Chromosomes Cancer 2002, 34:384-389.

10. Fukuhara $H$, Kuramochi M, Fukami $T$, Kasahara $K$, Furuhata $M$, Nobukuni T, Maruyama T, Isogai K, Sekiya T, Shuin T, Kitamura T, Reeves RH, Murakami Y: Promoter Methylation of TSLCI and Tumor Suppression by Its Gene Product in Human Prostate Cancer. Jpn J Cancer Res 2002, 93:605-609.

II. Hui AB, Lo KW, Kwong J, Lam EC, Chan SY, Chow LS, Chan AS, Teo PM, Huang DP: Epigenetic inactivation of TSLCI gene in nasopharyngeal carcinoma. Mol Carcinog 2003, 38: $170-178$.

12. Honda T, Tamura G, Waki T, Jin Z, Sato K, Motoyama T, Kawata S, Kimura W, Nishizuka S, Murakami Y: Hypermethylation of the TSLCI gene promoter in primary gastric cancers and gastric cancer cell lines. Jpn J Cancer Res 2002, 93:857-860.

13. Steenbergen RD, Kramer D, Braakhuis BJ, Stern PL, Verheijen RH, Meijer CJ, Snijders PJ: TSLCI gene silencing in cervical cancer cell lines and cervical neoplasia. J Natl Cancer Inst 2004, 96:294-305.

14. Fukami $T$, Fukuhara $H$, Kuramochi M, Maruyama $T$, Isogai $K$, Sakamoto M, Takamoto S, Murakami Y: Promoter methylation of the TSLCI gene in advanced lung tumors and various cancer cell lines. Int J Cancer 2003, 107:53-59. 
15. Masuda $M$, Yageta $M$, Fukuhara $H$, Kuramochi $M$, Maruyama $T$, Nomoto A, Murakami $Y$ : The tumor suppressor protein TSLCI is involved in cell-cell adhesion. J Biol Chem 2002, 277:31014-31019.

16. Shingai $\mathrm{T}$, Ikeda $\mathrm{W}$, Kakunaga $\mathrm{S}$, Morimoto $\mathrm{K}$, Takekuni $\mathrm{K}$, Itoh $\mathrm{S}$, Satoh K, Takeuchi M, Imai T, Monden M, Takai Y: Implications of nectin-like molecule 2/IGSF4/RAI75/SgIGSF/TSLCI/ SynCAMI in cell-cell adhesion and transmembrane protein localization in epithelial cells. J Biol Chem 2003.

17. Mao X, Seidlitz E, Ghosh K, Murakami Y, Ghosh HP: The cytoplasmic domain is critical to the tumor suppressor activity of TSLCI in non-small cell lung cancer. Cancer Res 2003, 63:7979-7985.

18. Yageta M, Kuramochi M, Masuda M, Fukami T, Fukuhara H, Maruyama T, Shibuya M, Murakami Y: Direct association of TSLCI and DAL-I, two distinct tumor suppressor proteins in lung cancer. Cancer Res 2002, 62:5129-5/33.

19. Gomyo H, Arai Y, Tanigami A, Murakami Y, Hattori M, Hosoda F, Arai K, Aikawa Y, Tsuda H, Hirohashi S, Asakawa S, Shimizu N, Soeda E, Sakaki Y, Ohki M: A 2-Mb sequence-ready contig map and a novel immunoglobulin superfamily gene IGSF4 in the LOH region of chromosome II q23.2. Genomics 1999, 62:139-146.

20. Biederer T, Sara Y, Mozhayeva M, Atasoy D, Liu X, Kavalali ET, Sudhof TC: SynCAM, a synaptic adhesion molecule that drives synapse assembly. Science 2002, 297:I525-I53I.

21. Wakayama T, Ohashi K, Mizuno K, Iseki S: Cloning and characterization of a novel mouse immunoglobulin superfamily gene expressed in early spermatogenic cells. Mol Reprod Dev 200I, 60:158-164.

22. Urase K, Soyama A, Fujita E, Momoi T: Expression of RAI75 mRNA, a new member of the immunoglobulin superfamily, in developing mouse brain. Neuroreport 200I, I 2:3217-322I.

23. Niklinski J, Niklinska W, Laudanski J, Chyczewska E, Chyczewski L: Prognostic molecular markers in non-small cell lung cancer. Lung Cancer 200I, 34 Suppl 2:S53-8.

24. Hirai K, Shimada H, Ogawa T, Taji S: The spread of human lung cancer cells on collagens and its inhibition by type III collagen. Clin Exp Metastasis 1991, 9:5 17-527.

25. Ito T, Shimada Y, Hashimoto Y, Kaganoi J, Kan T, Watanabe G Murakami Y, Imamura M: Involvement of TSLCI in progression of esophageal squamous cell carcinoma. Cancer Res 2003, 63:6320-6326

26. Dvorak HF: Vascular permeability factor/vascular endothelial growth factor: a critical cytokine in tumor angiogenesis and a potential target for diagnosis and therapy. J Clin Oncol 2002, 20:4368-4380

27. Kok K, Naylor SL, Buys CH: Deletions of the short arm of chromosome 3 in solid tumors and the search for suppressor genes. Adv Cancer Res 1997, 71:27-92.

28. Yang Y, Kiss H, Kost-Alimova M, Kedra D, Fransson I, Seroussi E, Li J, Szeles A, Kholodnyuk I, Imreh MP, Fodor K, Hadlaczky G, Klein G, Dumanski JP, Imreh S: A I-Mb PAC contig spanning the common eliminated region I (CERI) in microcell hybrid-derived SCID tumors. Genomics 1999, 62:147-I55.

29. Barradas M, Gonos ES, Zebedee Z, Kolettas E, Petropoulou C, Delgado MD, Leon J, Hara E, Serrano M: Identification of a candidate tumor-suppressor gene specifically activated during Rasinduced senescence. Exp Cell Res 2002, 273:127-137.

30. Mousses S, Bubendorf L, Wagner U, Hostetter G, Kononen J, Cornelison R, Goldberger N, Elkahloun AG, Willi N, Koivisto P, Ferhle W, Raffeld M, Sauter G, Kallioniemi OP: Clinical validation of candidate genes associated with prostate cancer progression in the CWR22 model system using tissue microarrays. Cancer Res 2002, 62: 1256-1260.

31. Guerreiro Da Silva ID, Hu YF, Russo IH, Ao X, Salicioni AM, Yang X, Russo J: SIOOP calcium-binding protein overexpression is associated with immortalization of human breast epithelial cells in vitro and early stages of breast cancer development in vivo. Int J Oncol 2000, 16:23I-240.

32. Beer DG, Kardia SL, Huang CC, Giordano TJ, Levin AM, Misek DE, Lin L, Chen G, Gharib TG, Thomas DG, Lizyness ML, Kuick R, Hayasaka S, Taylor JM, lannettoni MD, Orringer MB, Hanash S: Geneexpression profiles predict survival of patients with lung adenocarcinoma. Nat Med 2002, 8:816-824.

33. Brandt B, Roetger A, Bidart JM, Packeisen J, Schier K, Mikesch JH, Kemming D, Boecker W, Yu D, Buerger H: Early placenta insulin- like growth factor (pro-EPIL) is overexpressed and secreted by c-erbB-2-positive cells with high invasion potential. Cancer Res 2002, 62: 1020-1024.

34. Pishvaian MJ, Feltes CM, Thompson P, Bussemakers MJ, Schalken JA, Byers SW: Cadherin- $I I$ is expressed in invasive breast cancer cell lines. Cancer Res 1999, 59:947-952.

35. Feltes CM, Kudo A, Blaschuk O, Byers SW: An alternatively spliced cadherin-II enhances human breast cancer cell invasion. Cancer Res 2002, 62:6688-6697.

36. Shibata T, Ochiai A, Kanai Y, Akimoto S, Gotoh M, Yasui N, Machinami R, Hirohashi S: Dominant negative inhibition of the association between beta-catenin and c-erbB-2 by $\mathrm{N}$-terminally deleted beta-catenin suppresses the invasion and metastasis of cancer cells. Oncogene 1996, 13:883-889.

37. Retera JM, Leers MP, Sulzer MA, Theunissen PH: The expression of beta-catenin in non-small-cell lung cancer: a clinicopathological study. J Clin Pathol 1998, 51:891-894.

38. Mao X, Seidlitz E, Truant R, Hitt M, Ghosh HP: Re-expression of TSLCI in a non-small-cell lung cancer cell line induces apoptosis and inhibits tumor growth. Oncogene 2004, 23:5632-5642.

39. Feinberg AP, Vogelstein B: A technique for radiolabeling DNA restriction endonuclease fragments to high specific activity. Anal Biochem 1983, 132:6-13.

40. Schwartz DC, Cantor CR: Separation of yeast chromosomesized DNAs by pulsed field gradient gel electrophoresis. Cell 1984, 37:67-75

4I. Liu HC, Mele C, Catz D, Noyes N, Rosenwaks Z: Production of insulin-like growth factor binding proteins (IGFBPs) by human endometrial stromal cell is stimulated by the presence of embryos. J Assist Reprod Genet 1995, 12:78-87.

42. Tarrade A, Rochette-Egly C, Guibourdenche J, Evain-Brion D: The expression of nuclear retinoid receptors in human implantation. Placenta 2000, 21:703-710.

43. Kao LC, Tulac S, Lobo S, Imani B, Yang IP, Germeyer A, Osteen K, Taylor RN, Lessey BA, Giudice LC: Global gene profiling in human endometrium during the window of implantation. Endocrinology 2002, |43:2|1 9-2/38.

44. Chen GT, Getsios S, MacCalman CD: Cadherin-II is a hormonally regulated cellular marker of decidualization in human endometrial stromal cells. Mol Reprod Dev 1999, 52:158-165.

45. Tsai SJ, Wu MH, Chen HM, Chuang PC, Wing LY: Fibroblast growth factor-9 is an endometrial stromal growth factor. Endocrinology 2002, I 43:27I 5-272I.

46. Mock P, Frydman R, Bellet D, Diawara DA, Lavaissiere L, Troalen F, Bidart JM: Pro-EPIL forms are present in amniotic fluid and maternal serum during normal pregnancy. J Clin Endocrinol Metab 1999, 84:2253-2256.

47. Morrish DW, Linetsky E, Bhardwaj D, Li H, Dakour J, Marsh RG, Paterson MC, Godbout R: Identification by subtractive hybridization of a spectrum of novel and unexpected genes associated with in vitro differentiation of human cytotrophoblast cells. Placenta 1996, 17:431-44I. 